\title{
Investigation of the Relationship between Corporate Governance and Financial Management Decisions in Firms Listed in Tehran Stock Exchange Market
}

\author{
Roghayeh Manafi \\ Department of Financial Management, Sari Branch, Islamic Azad University, Sari, Iran \\ R.phd92@yahoo.com
}

\section{Dr. Amir Mahmoudian*}

Department of Accounting, Savadkooh Branch, Islamic Azad University, Savadkooh, Iran Amirmahmoudian@yahoo.com

\section{Dr. Ali Zabihi}

Department of Accounting, Aliabad Katoul Branch, Islamic Azad University, Aliabad Katoul, Iran Zabihi52@yahoo.com

\section{Doi:10.5901/mjss.2015.v6n5p88}

\section{Abstract}

In this research, the relationship between corporate governance and financial management decisions such as earnings management and inappropriate investments is explored. Data of 110 companies listed in Tehran Stock Exchange market from 2007 to 2013 has been used. The method for testing the hypotheses was linear regression. The results showed a negative and meaningful relationship between ownership concentration and CEO duality with earnings management. Institutional ownership has a positive and meaningful relationship with earnings management. Management ownership and earnings management have no meaningful relationship. Also, other results show that management ownership has a negative and meaningful relationship with investment efficiency and other corporate governance mechanisms have no meaningful relationship with investment efficiency.

Keywords: corporate governance- financial management decisions-investment

\section{Introduction}

Corporate governance in recent years has appealed to many people. This is due to the attention paid to economic health of the society and specifically commercial units. Especially that extreme increase in corporate frauds and consequent scandals of their discovery in recent decades has emphasized the necessity of using enterprise management system mechanisms. Corporate governance system as a system connecting different scientific branches such as accounting, financial management, economy and law and with maintaining balance of social and economic goals with individual and group goals leads to encouragement and enhancement of efficient and optimal use of resources and accountability of companies in regard to other stakeholders in the company. On the other hand, implementation of corporate governance system can help optimal specialization of resources and improvement of financial information transparency in the market and consequently economic development (John and Senbet, 1998, quoted in Ghaemi and Shahriari, 2009; 114). The ultimate goal of corporate governance is reaching responsibility, transparency, justice and respecting stakeholders' rights in firms. Among these, accountability is the essence of corporate governance and its proper implementation will facilitate reaching the other three goals (Hasas Yegane,2006;34).

\section{Literature Review}

Rahbary Kharazi (2005), by exploring the conditions of corporate governance in firms listed in Iran Stock Exchange Market and comparing them with world countries, has studied shareholders' rights. The results revealed that shareholders' rights are not respected in Iran.

Yazdanian (2006) has investigated the impact of several criteria of corporate governance on the decrease in 
earnings management. He found out that only the presence of institutional shareholders affects the decrease in earnings management, while the presence of external members of board of directors, segregation of CEO and chairman's role and also presence of internal auditor does not influence earnings management.

Hasas Yeganeh et. Al, (2008) examined the relationship between institutional investors and firm value. They used multiple linear regressions for testing their research hypothesis. The results confirmed the existence of a positive relationship between institutional investors and firm value.

By examining the relationship between corporate governance and earnings management in Tehran exchange market companies, Hasas Yegane et. Al, (2008) realized that there is no meaningful relationship between these mechanisms, including the number of board of directors' members, number and efficiency of external managers, segregation of CEO and chairman duties or his/her membership in the board of directors, ownership structure and existence of internal audit.

Zhou and Wang (1999) studied the relationship between ownership structure and corporate governance in China stock market. Findings demonstrated that institutional investors have a positive effect on the profitability. Many of the research done in the field of corporate governance mechanisms in companies emphasize this fact that weakness in corporate governance mechanisms in a firm is related to low quality of financial statements report, income and earnings fraud and manipulation and also low information transparency (Beasley et. Al, 2000, Carsello and Neal, 2000; Fellow et al., 2001 ).

Yermack (2004) with a population of 452 companies from 1991-2003, showed that when CEO and chairman are different, firm has more value.

Gonzalez and Mocha (2014), in their research, investigated the impact of corporate governance strategies on earnings management in Latin American countries. Results of the research showed that ownership concentration has negative and meaningful and management ownership has positive and meaningful impact on firm earnings. Furthermore, other results of their research showed that corporate management mechanisms lack proper efficiency and productivity for improving performance and operation of the firms under study.

Avvgbh and Peter (2014) explored the impacts of corporate governance strategies on earnings management in Nigeria Stock Exchange Market. They realized that the variables of CEO task duality and institutional shareholders' percentage have negative and meaningful relationship with earnings management.

In another research, Panayides and Andreo (2014) explored the correlation between corporate governance and financial management decisions such as unpleasant investments and profit management in marine companies. Findings revealed the relationship between corporate governance and financial management decisions. In this study, the variables of the size of board of directors, internal management ownership, presence of corporate supervision committees and CEO task duality were examined.

Results of their project also demonstrated that there is a negative correlation between variables such as the size and independence of board of directors with profit management.

\section{Research Hypotheses}

First hypothesis: There is a meaningful relationship between ownership management and firms' earnings management.

Second hypothesis: There is a meaningful relationship between the percentage of institutional shareholders and earnings management.

Third hypothesis: There is a meaningful relationship between the percentage of block shareholders and earnings management.

Fourth hypothesis: There is a meaningful relationship between CEO task duality and earnings management.

Fifth hypothesis: There is a meaningful relationship between management ownership and investment efficiency.

Sixth hypothesis: There is a meaningful relationship between the percentage of institutional shareholders and investment efficiency.

Seventh hypothesis: There is a meaningful relationship between the percentage of block shareholders and investment efficiency.

Eighth hypothesis: There is a meaningful relationship between the CEO task duality and investment efficiency.

\section{Research Methodology}

Statistical population

Research population of the current study consists of all firms listed in Tehran Stock Exchange Market in a 7-year 
period from 2007 to 2013. In this research, among all the companies, those which lacked any of the following requirements were omitted and eventually all the remaining firms were selected for performing the test.

- Companies should own full information for all financial statements such as balance sheet, cash flow statements, and income statement.

- Their financial year should end in Esfand 29th.

- Companies should be active in stock exchange market during research period.

- They shouldn't change their financial year during research.

- Company should not be of investment or financial intermediary type.

Based on the stated limitations, 110 companies were selected and investigated as statistical population in the present research.

\section{Method of Data Collection and Analysis}

Data collection was done in 2 stages in this research. In the first stage, for formulation of theoretical foundation of research, library method and for the second stage, for data collection, sample companies' documents and papers, such as financial statements in CDs presented by Tehran Stock Exchange and Research, Development and Islamic Studies Management of Stock Exchange (http://rdis.ir) have been used. Analysis of data and test of hypotheses were done through linear regression and Eviews software.

For analyzing each of the hypotheses, cross-sectional and compositional data were used. Also, for analysis of research hypotheses, we relied on the findings related to model estimation at compositional data level. Moreover, in order to examine the hypotheses test results, T-test for meaningfulness of coefficients and F-test for meaningfulness of the whole model were used and also, 12 adjusted $\mathrm{R}^{2}$ was used for the relationship between dependent and independent variables.

\section{Variables and Research Model}

Independent Variable

Corporate governance that is measured by the following criteria:

- The percentage of company shares that are held by board of directors.

- The percentage of company shares that are held by institutional shareholders. (institutional shareholders involve all legal shareholders)

- The number of block shareholders whose ownership percentage is more than 5 percent of company shares.

- Duality of CEO tasks; that is when CEO is the same as chairman of board of directors.

Dependent Variable

1. Earnings management that is calculated through modified Jones model (1991).

$T A_{i, t}=\alpha_{1}+\alpha_{2}\left(\Delta\right.$ Sales $\left._{i, t}-\Delta A R_{i t}\right)+\alpha_{3} P P E_{i t}+\alpha_{4} B M_{i t}+\alpha_{5} C F O_{i t}+\varepsilon_{i t}$ cash flow.

TA: Total accruals of the firm that is calculated by difference of before extraordinary items earnings and operating

$\Delta$ Sales $_{i, t}=$ changes in sales from last year to current year

$\triangle A R_{i t}=$ accounts receivable difference from last to current year.

$P P E_{i t}=$ fixed assets

$\mathrm{BM}=$ book value of ordinary shares to ordinary shares market

$\mathrm{CFO}_{i t}=$ company operating cash flow

Modified Jones model remainder shows firm earnings management; the bigger the remaining modulus, there is a higher possibility of firm earnings management and if the model's remaining modulus is smaller and close to zero, the possibility of firm earnings management is lower.

2. Investment Efficiency:

This variable signifies lack of overinvestment and underinvestment based on financial manager decisions and

it is calculated by the remainder of following model, which was developed by Richardson (2006):

$I E_{t}=\alpha_{1}+\alpha_{2} Q_{t-1}+\alpha_{3} A G E_{t-1}+\alpha_{4} S I Z E_{t-1}+\alpha_{5} L E V_{t-1}+\alpha_{6} C A S H_{t-1}+\varepsilon_{t}$

$\mathrm{IE}=$ net investment expenses

$\mathrm{Q}=$ Firm Tobin's $\mathrm{Q}$

AGE = Firm age 


\section{SIZE=Firm size}

LEV=Firm leverage

$\mathrm{CASH}=$ firm cash

Control variable

Firm size: this criterion is obtained through natural logarithm of total assets

Financial leverage: it is calculated through division of total debts to total assets

In the current project, the relationship between corporate governance and decisions of financial managers of firms listed in Tehran Exchange Market is tested. Research regression models are as follows:

Pattern 1:

$D A_{t}=\alpha_{1}+\alpha_{2} D U A L_{i t}+\alpha_{3} \operatorname{COOW}_{i t}+\alpha_{4} I N S_{i t}+\alpha_{5} M G T_{i t}+\alpha_{6} L E V_{i t}+R O A_{i t}+S I Z E_{i t}+\varepsilon_{t}$

This model is used for testing hypotheses one to four.

Pattern 2

$R_{-} I E_{t}=\alpha_{1}+\alpha_{2}$ DUAL $_{i t}+\alpha_{3}$ COOW $_{i t}+\alpha_{4} I N S_{i t}+\alpha_{5} M G T_{i t}+\alpha_{6} L E V_{i t}+R O A_{i t}+S I Z E_{i t}+\varepsilon_{t}$

This model is used for testing hypotheses five to eight.

\section{Research Findings}

Results of table.1 demonstrate that Tobin's Q dependant variables' average equals (1.4221), average accruals (0.1391) and average investment is (0.5616). Moreover, based on pattern 1, average value for block and institutional shareholders and management' ownership structures is $0.7587,0.7198$ and 0.6734 ,respectively that implies the fact that a limited number of institutional are members of the board of directors and are able to lead firm decisions. Also, Standard deviation, kurtosis and skewness statistics (presented in the appendix) can be used for exploring normal distribution of data (Claire and Varak, 2003). Examining the foresaid criteria, it can be said that the data related to independent and dependant variables have normal distribution, because variables have the least difference from the presented value for kurtosis. Vovs (2002) states that when the size of a sample is bigger than 100 (an approximate criterion for normal distribution) increases the possibility of normal data.

Table 1. Descriptive Statistics of Variables

\begin{tabular}{|l|c|c|c|c|c|c|}
\hline Variable & number & average & mean & Standard deviation & maximum & Minimum \\
\hline Tobin's Q & 741 & 1.4221 & 1.2362 & 0.5919 & 4.6015 & 0.3227 \\
\hline Ownership concentration & 741 & 0.758 & 0.8080 & 0.1799 & 0.9998 & 0.0395 \\
\hline CEO duality & 741 & 0.9109 & 1.0000 & 0.2850 & 1.0000 & 0.0000 \\
\hline Institutional ownership & 741 & 0.7195 & 0.8173 & 0.2687 & 0.9900 & 0.0100 \\
\hline Management ownership & 741 & 0.6734 & 0.6980 & 0.1962 & 0.9900 & 0.0100 \\
\hline Financial leverage & 741 & 0.6523 & 0.6576 & 0.1673 & 0.9714 & 0.0964 \\
\hline Return on assets & 741 & 0.5300 & 0.3945 & 0.5514 & 2.9358 & -1.3856 \\
\hline Firm size & 741 & 5.7298 & 5.6808 & 0.5918 & 7.9568 & 4.2464 \\
\hline Book-to-market value ration & 741 & 0.7946 & 0.8089 & 0.2506 & 3.0979 & 0.2173 \\
\hline Accruals & 741 & 0.1391 & 0.0532 & 0.6396 & 4.4294 & -7.1403 \\
\hline Firm size & 741 & 33.2361 & 36.0000 & 0.5886 & 57.0000 & 6.0000 \\
\hline Investments expenses & 741 & 0.8616 & 0.4618 & 12.0738 & 3.7974 & 0.0005 \\
\hline Cash & 741 & 0.1810 & 0.0556 & 0.2556 & 0.9778 & 0.0556 \\
\hline
\end{tabular}

\section{Results of Testing Hypotheses}

Table.2 shows the results of assessing research model 1. For this model Durbin-Watson Statistic equals 1.786 and the error term is rejected at 5 error level. The possibility value related to $\mathrm{F}$ statistic is less than 5 percent for specification. This way, null hypothesis based on model specification error is rejected. As a result, meaningfulness of the model is accepted with 95percent certainty. Adjusted R-square equals 0.31 . This test reflects that about 31 percent of dependent variable changes can be described by independent variables. Since model test was not rejected, research hypotheses are investigated. 
Table 2. Results of assessing research model 1

\begin{tabular}{|l|c|c|c|}
\hline Variable & Coefficient & t-statistic & Error level \\
\hline y-intercept & -0.1060 & -1.3225 & 0.1864 \\
\hline Ownership concentration & -0.3399 & -4.0985 & 0.0000 \\
\hline CEO duality & -0.0637 & -2.3113 & 0.0211 \\
\hline Institutional ownership & 0.1603 & 3.8059 & 0.0002 \\
\hline management ownership & 0.0620 & 0.9507 & 0.3420 \\
\hline Financial leverage & 0.3260 & 7.3795 & 0.0000 \\
\hline Return on assets & 0.4367 & 18.1013 & 0.0000 \\
\hline Firm size & -0.0337 & -2.7856 & 0.0055 \\
\hline R-square & 0.3189 & & \\
\hline Adjusted R-square & 0.3125 & & \\
\hline Durbin-Watson Statistic & 1.7868 & & \\
\hline F Statistic & 50.1707 & & \\
\hline F Statistic Possibility & 0.0000 & & \\
\hline
\end{tabular}

Hypothesis No. 1

The purpose of this hypothesis is investigating the existence of a meaningful relationship between block shareholders percentage (ownership concentration) and earnings management. Therefore, null and alternative statistical hypotheses are as follows:

Null hypothesis: there is not a meaningful relationship between block shareholders' percentage (ownership concentration) and earnings management.

Hypothesis: there is a meaningful relationship between block shareholders' percentage (ownership concentration) and earnings management.

According to the results presented in table 2, possibility error level related to null hypothesis is based on the lack of meaningful impact of ownership concentration on earnings management is 0.0000 that is smaller than 0.05 . Hence, null hypothesis is rejected. Consequently, ownership concentration has a meaningful and negative relationship with earnings management.

Hypothesis No. 2

The goal of this hypothesis is to explore if there is a meaningful relationship between CEO task duality and earning management. Therefore, statistical null and alternative hypotheses are as follows:

Null hypothesis: There is no meaningful relationship between CEO task duality and earnings management.

Alternative hypothesis: there is a meaningful relationship between CEO task duality and earnings management.

According to the findings presented in table 2, possible error rate of null hypothesis based on the lack of meaningful impact of CEO duality on financial performance equals 0.0211 that is smaller than 0.05 . Hence, null hypothesis is rejected. As a result, CEO duality has a meaningful and negative impact on earnings management.

Hypothesis No. 3

The goal of this hypothesis is to explore if there is a meaningful relationship between institutional ownership and earnings management.

Therefore, statistical null and alternative hypotheses are as follows:

Null hypothesis: There is no meaningful relationship between institutional ownership and earnings management.

Alternative hypothesis: there is a meaningful relationship between institutional ownership and earnings management.

According to the findings presented in table 2, possible error rate of null hypothesis based on the lack of meaningful impact of institutional ownership on earnings management equals 0.0002 that is smaller than 0.05 . Hence, null hypothesis is rejected. As a result, institutional ownership has a meaningful impact on earnings management.

Hypothesis No. 4

The goal of this hypothesis is to explore if there is a meaningful relationship between management ownership and earnings management. Therefore, statistical null and alternative hypotheses are as follows:

Null hypothesis: There is no meaningful relationship between management ownership and earnings management.

Alternative hypothesis: there is a meaningful relationship between management ownership and earnings management.

According to the findings presented in table 2, possible error rate of null hypothesis based on the lack of meaningful impact of institutional ownership on earnings management equals 0.3420 that is bigger than 0.05 . Hence, null 
hypothesis is not rejected. As a result, institutional ownership has no meaningful impact on earnings management.

Table.3 shows the results of assessing research model 2. For this model Durbin-Watson Statistic equals 2.3112 and the error term is rejected at 5 error level. The possibility value related to $\mathrm{F}$ statistic is less than 5 percent for specification. This way, null hypothesis based on model specification error is rejected. As a result, meaningfulness of the model is accepted with 95percent certainty. Adjusted R-square equals 0.2185 . This test reflects that about 22 percent of dependent variable changes can be described by independent variables. Since model statistic was not rejected, research hypotheses are investigated.

Table 3. Results of assessing research model 2

\begin{tabular}{|l|c|c|c|}
\hline Variable & Coefficient & t-statistic & Error level \\
\hline y-intercept & 0.2241 & 0.7910 & 0.4292 \\
\hline Ownership concentration & -0.0700 & -0.4491 & 0.6535 \\
\hline CEO duality & 0.0445 & 1.0300 & 0.30334 \\
\hline Institutional ownership & 0.1859 & -0.8127 & 0.4167 \\
\hline management ownership & -0.3387 & -2.1221 & 0.0342 \\
\hline Financial leverage & 0.1353 & 1.0394 & 0.2990 \\
\hline Return on assets & 0.0190 & -0.3826 & 0.7021 \\
\hline Firm size & 0.0134 & 6267 & 0.5310 \\
\hline R-square & 0.3383 & & \\
\hline Adjusted R-square & 0.2185 & & \\
\hline Durbin-Watson Statistic & 2.3112 & & \\
\hline F Statistic & 2.8252 & & \\
\hline F Statistic Possibility & 0.0000 & & \\
\hline
\end{tabular}

Hypothesis No. 5

The goal of this hypothesis is to explore if there is a meaningful relationship between the ownership percentage of block shareholders (ownership concentration) and investment efficiency. Therefore, statistical null and alternative hypotheses are as follows:

Null hypothesis: There is no meaningful relationship between the ownership percentage of block shareholders (ownership concentration) and investment efficiency.

Alternative hypothesis: There is a meaningful relationship between the ownership percentage of block shareholders (ownership concentration) and investment efficiency.

According to the findings presented in table 3 , possible error rate of null hypothesis based on the lack of meaningful impact of ownership percentage of block shareholders (ownership concentration) and investment efficiency equals 0.6535 that is bigger than 0.05 . Hence, null hypothesis is not rejected. As a result, ownership concentration has no meaningful impact on earnings investment efficiency.

Hypothesis No. 6

The goal of this hypothesis is to explore if there is a meaningful relationship between CEO task duality and investment efficiency. Therefore, statistical null and alternative hypotheses are as follows:

Null hypothesis: There is no meaningful relationship between CEO task duality and investment efficiency.

Alternative hypothesis: there is a meaningful relationship between CEO task duality and investment efficiency.

According to the findings presented in table 3 , possible error rate of null hypothesis based on the lack of meaningful impact of CEO duality on investment efficiency equals 0.3034 that is bigger than 0.05 . Hence, null hypothesis is not rejected. As a result, CEO duality does not have a meaningful impact on investment efficiency.

Hypothesis No. 7

The goal of this hypothesis is to explore if there is a meaningful relationship between institutional ownership and investment efficiency. Therefore, statistical null and alternative hypotheses are as follows:

Null hypothesis: There is no meaningful relationship between institutional ownership and investment efficiency. efficiency.

Alternative hypothesis: there is a meaningful relationship between institutional ownership and investment

According to the findings presented in table 3 , possible error rate of null hypothesis based on the lack of meaningful impact of CEO duality on investment efficiency equals 0.4167 that is bigger than 0.05 . Hence, null hypothesis 
is not rejected. As a result, CEO duality does not have a meaningful impact on investment efficiency.

Hypothesis No. 8

The goal of this hypothesis is to explore if there is a meaningful relationship between management ownership and investment efficiency. Therefore, statistical null and alternative hypotheses are as follows:

Null hypothesis: There is no meaningful relationship between management ownership and investment efficiency. efficiency.

Alternative hypothesis: there is a meaningful relationship between management ownership and investment

According to the findings presented in table 3, possible error rate of null hypothesis based on the lack of meaningful impact of CEO duality on investment efficiency equals 0.0342 that is smaller than 0.05 . Hence, null hypothesis is rejected. As a result, management ownership has a meaningful and negative impact on investment efficiency.

\section{Conclusion}

In this research, the relationship between corporate governance including ownership concentration, institutional ownership and board of directors' task duality in regard to financial management's decisions was studied. Two criteria for financial management decisions were used in this research that consist of profit management and investment efficiency, and in this respect, the study is similar to that of Panayiotis et al. (2015). Although some of the used variables for measuring the two criteria and also broader range of the companies selected are the points of difference. As it was mentioned, one of the measuring criteria for financial management decisions in this research is profit management. Therefore, this project showed there is a negative and significant correlation between ownership concentration and CEO duality with profit management that is consistent with Avvgubh and Peter (2014)'s research and also institutional ownership has a meaningful and positive relationship with profit management that is consistent with Yazdanian research. Moreover, the results revealed that management ownership do not have meaningful relationship with profit management that is similar to the findings of Hasas Yeganeh et al.,and there is a negative and significant relationship between other corporate governance mechanisms with investment efficiency. Other corporate governance mechanisms do not have any significant relationship with investment coefficient.

\section{References}

Andreou, P.C., Louca, C., Panayides, P.M., 2012. Valuation effects of mergers and acquisitions in freight transportation. Transp. Res. Part E 48, 1221-1234.

Ashbaugh-Skaife, H., Collins, D.W., LaFond, R., 2006. The effects of corporate governance on firms' credit ratings. J. Account. Econ. 4, 203-243.

Bebchuk, L., Cohen, A., 2004. The Costs of Entrenched Boards. Working Paper. Harvard Law School.

Bebchuk, L., Cohen, A., Ferrell, A., 2004. What Matters in Corporate Governance? Working Paper. Harvard Law School.

Bebchuk, L.A., Stole, L., 1993. Do short-term managerial objectives lead to under- or over-investment in long-term projects? J. Financ. $48,719-729$

Bebchuk, L.A., Weisbach, M.S., 2010. The state of corporate governance research. Rev. Financ. Stud. 23, 939-961.

Beneish, M., Vargus, M., 2002. Insider trading, earnings quality, and accrual mispricing. Account. Rev. 4, 755-791.

Bertrand, M., Mullainathan, S., 2003. Enjoying the quite life? Corporate governance and managerial preferences. J. Polit. Econ. 111 (5), 1043-1075.

Bhagat, S., Black, B., 2002. The non-correlation between board independence and long-term firm performance. J. Corp. L. 27, $231-274$.

Bhagat, S., Bolton, B., 2008. Corporate governance and firm performance. J. Corp. Gov. 14, 257-273.

Billett, M., Garfinkel, J., Jiang, Y., 2011. The influence of governance on investment: evidence from a hazard model. J. Financ. Econ. $102(3), 643-670$.

Bohren, O., Cooper, I., Priestley, R., 2009. Real Investment, Economic Efficiency, and Managerial Entrenchment. Working Paper, Tel Aviv University.

Brian J. Bushee, Mary Ellen Carter, Joseph Gerakos.2010. Institutional Investor Preferences for Corporate Governance Mechanisms. Managing corporate performance.

Brown, P., Beekes, W., Verhoeven, P., 2011. Corporate governance, accounting and finance: a review. Account. Financ. 51, $96-172$.

Burns, N., Kedia, S., 2006. The impact of performance-based compensation on misreporting. J. Financ. Econ. 79, 35-67.

Bushee, B.J., 1998. Investors on myopic R\&D investment behavior. Account. Rev. 73 (3), 305-333.

Bushee, B.J., 2001. Do institutional investors prefer near-term earnings over long-run value? Contemp. Account. Res. 18 (2), $207-246$.

Canil, J., Rosser, B., 2012. Australian evidence on CEO option grants. Multinat. Financ. J. 16, 225-260.

Charitou, A., Louca, C., Panayides, S., 2007. Cross-listing bonding hypothesis and corporate governance. J. Bus. Financ. Account. 34 (7\&8), 1281-1306. 
Chen, I.J., Lin, S.H., 2014. Managerial optimism, investment efficiency, and firm valuation. Multinat. Financ. J. 17 (3/4), 1-48.

Coles, J.L., Naveen, D.D., Naveen, L., 2008. Boards: does one size fit all? J. Financ. Econ. 87, 329-356.

Cornett, M.M., Marcus, A.J., Tehranian, H., 2008. Corporate governance and pay-for performance: the impact of earnings management. J. Financ. Econ. 87 (2),

Cubbin, J.S., Hall, G., 1983. Directors' remuneration in the theory of the firm: specification and testing of the null hypothesis. Eur. Econ. Rev. 20, 333-348.

Dalton, D.R., Daily, C.M., Ellstrand, A.E., Johnson, J.L., 1998. Meta-analytic reviews of board composition, leadership structure, and financial performance.

Dalton, D.R., Daily, C.M., Johnson, J.L., Ellstrand, A.E., 1999. Number of directors and financial performance: A meta-analysis. Acad. Manag. J. 42 (6), 674-686.

Davidson III, W.N., Xie, B., Xu, W., 2004. Market reaction to voluntary announcements of audit committee appointments: the effect of financial expertise. J.Account. Public Policy 23 (4), 279-293.

Garry, Bruton; Igor ,Filatotchev; Salim, Chahine; Mike, Wright. Governance, Ownership Structure and Performance of IPO Firms:The Impact of Different Types of Private Equity Investors and Institutional Environments. Strategic Management Journal, forthcoming.

Gillan, S., and L. Starks. 2000. Corporate governance proposals and shareholder activism: The role of institutional investors. Journal of Financial Economics 57:275-305.

Gu", ler Aras; Aslı ,Aybars; Ozlem, Kutlu. 2008-2009. Investigating the relationship between corporate social responsibility and financial performance in emerging markets. Managing corporate performance.

Nousheen Tariq Bhutta*, Syed Zulfiqar Ali Shah.2014. Investors'Reaction to the Implementation of Corporate Governance Mechanisms. Journal of Accounting, 3, 3-8

Nousheen Tariq Bhutta*, Syed Zulfiqar Ali Shah.2014. Investors'Reaction to the Implementation of Corporate Governance Mechanisms. Journal of Accounting, 3, 3-8

Panayiotis C. Andreou, Christodoulos Louca, Photis M. Panayides, Corporate governance, financial management decisions and firm performance: Evidence from the maritime industry. 2015. journal homepage: www.elsevier.com/locate/tre.

Shleifer, A., and R. Vishny. 1997. A survey of corporate governance. Journal of Finance 52:737-83.Strateg. Manag. J. 19 (3), 269-290.

Yermack, D (1996), „Higher market valuation of companies with a small board of directors", Journal of Financial Economics, vol. 40, no. 2, pp.185-215.http://www.businessdictionary.com/definition/financial-performance.html 